\title{
The Effect of Earnings Quality on Financial Analysts' Dividend Forecast Accuracy: Evidence from Korea*
}

\author{
Hye-Jeong NAM ${ }^{1}$ \\ Received: July 17, 2019 Revised: September 05, 2019 Accepted: September 24, 2019
}

\begin{abstract}
Dividend policy is an important business decision and is considered a channel to communicate a firm's performance to shareholders. Given the empirical findings that earnings quality significantly affects financial analysts' forecasting activities, it is predicted that higher earnings quality would positively influence forecast accuracy. Specifically, it is expected that financial analysts would forecast dividends more accurately for firms with higher earning quality. Unlike the research on financial analysts' earnings forecasts was heavily conducted, there is little study about financial analysts' dividend forecasts. This paper examines the effect of earnings quality on financial analysts' dividend forecast accuracy. We use a sample of South Korean firms for the period of 2011-2015 for multivariate regression. Earnings quality is measured by accruals quality and performance-adjusted discretionary accruals followed by prior studies. We first compare the accuracy between dividend forecasts and earnings forecasts using t-test and Wilcoxon singed-rank test. It is confirmed that financial analysts' dividend forecasts are more accurate than earnings forecasts in Korea. We find that financial analysts' dividend forecasts are more accurate for firms with higher earnings quality. We also find that the result is still valid after controlling for the accuracy of financial analysts' earnings forecasts. This confirms that earnings quality positively affects financial analysts' dividend forecasts.
\end{abstract}

Keywords : Eamings Quality, Dividend Forecasts, Eamings Forecasts, Accuracy of Dividend Forecasts, Accuracy of Earnings Forecasts

JEL Classification Code : M40, M41, M49, G17

\section{Introduction}

According to dividend signaling theory, dividend payouts signal a company's future performance. Dividend also provides useful implications about future cash flow, valuation, or dividend arbitrage transactions. The firm's dividend policy is critical information because investors would prefer dividends rather than capital gains when they consider taxes and transaction costs (Brown \& Clarke, 1993). Therefore, accurate information about future dividends can

\footnotetext{
* This work was supported by the Ministry of Education of the Republic of Korea and the National Research Foundation of Korea (NRF-2017S1A5A2A01023543).

1 Professor, Business School, Dongguk University-Seoul. [30, Pildong-ro 1 gil, Jung-gu, Seoul, 04620, Korea] Email: namhj@dongguk.edu

(c) Copyright: Korean Distribution Science Association (KODISA)

This is an Open Access article distributed under the terms of the Creative Commons Attribution Non-Commercial License (http://Creativecommons.org/licenses/by-nc/4.0/) which permits unrestricted noncommercial use, distribution, and reproduction in any medium, provided the original work is properly cited.
}

be very useful to investors' decision making.

Despite of usefulness of dividend forecasts on a firm's value (Foster \& Vickrey, 1978), research on dividend forecasts is scarce. Unlike dividend forecasts, earnings forecasts have been actively investigated for quite some time and are used for both corporate valuation and future growth forecasting (O'Brien, 1988; Hwang, Jan, \& Basu, 1996; Daniel \& Titman, 2006). This study extends forecasts studies by examining the effect of earnings quality on the accuracy of financial analysts' dividend forecasts. Specifically, this paper examines the effects of earnings quality on dividend forecasts in Korea, and tests whether high quality earnings influence the accuracy of financial analysts' dividend forecasts

As dividend yields in Korea have recently surpassed market interest rates, interest in dividend payouts has been increasing. According to Korea Capital Market Institute (KCMI) report (2016), the total dividend in the Korea Composite Stock Price Index was 19 trillion KRW, which was an increase of $27.1 \%$ over the previous year. The 
dividend payout ratio of KOSPI-listed companies has been increasing since 2012, with an average increase of $27.2 \%$ over the past two years. Compared with the dividend payout ratio of 19 major countries from 2005 to 2011, Korea's dividend payout ratio is about $22 \%$, which is lower than the average dividend payout ratio of other countries, which is $49 \%$.

This emphasizes the importance of dividends in corporations' decision making. In response to increased interest in dividends, SamSung (www.samsung.com), which is the largest company in Korea announced that they disclose dividend amount over the next three years to increase dividend forecasting. However, despite the demand for dividend forecasts in the market, empirical studies on dividend forecasts are rare.

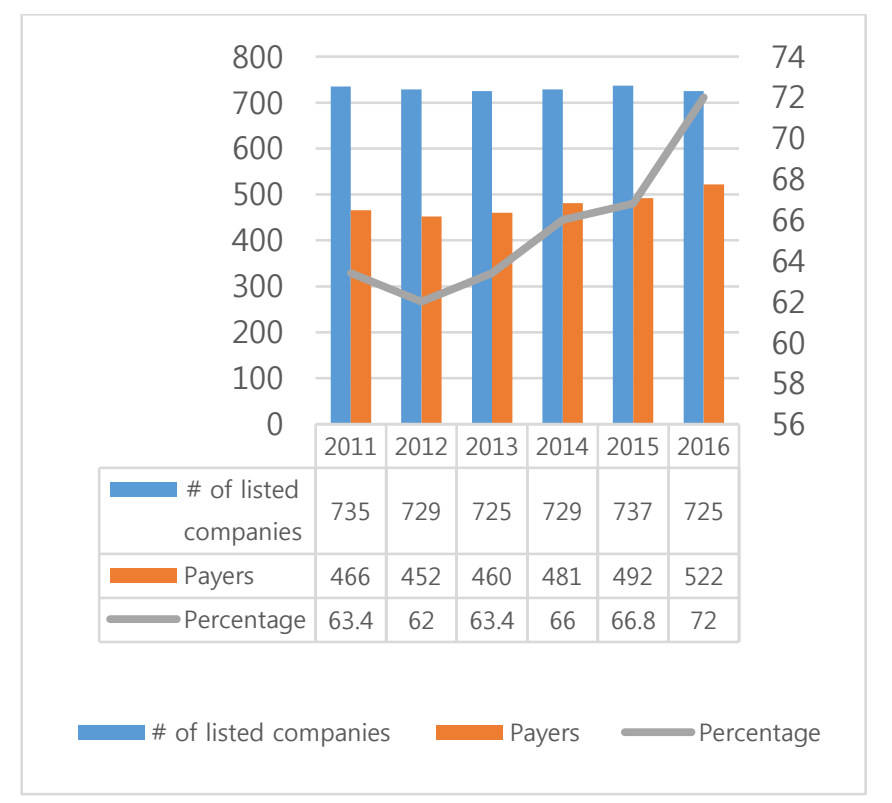

Figure 1: The Number of Dividend Payers in Korea (2011-2016)

Given the increase in demand of dividend forecasts and dividend payers in Korea, this paper explores the effect of earnings quality on financial analysts' dividend forecasts. Financial analysts use accounting information as a basic and important resource when estimating a firm's value. Among accounting information, earnings significantly affect financial analysts' forecasting activities (Basi, Carey, \& Twark, 1976; Eddy \& Seifert, 1992; Imhoff, 1992). Therefore, earnings with high quality are useful for financial analysts' forecasts. Like earnings forecasts, dividend forecasts are based on a firm's performance because a dividend policy is essentially determined by making predictions about a firm's future performance. It is expected that the more predictable earnings, the more predictable dividend forecasts. This study tests this prediction by first examining the accuracy of dividend forecasts provided by financial analysts and comparing their accuracy with that of earnings forecasts. The differences between the accuracy of the dividend forecasts and the accuracy of the earnings forecasts can be verified using the Wilcoxon signed-rank test. Second, this paper examines whether better quality of earnings positively affects analysts' dividend forecast accuracy using two measurements as proxies for earnings quality. The first measurement for earning quality is the absolute value of variation of discretionary accruals followed by Francis, LaFond, Olsson, and Schipper (2005). Since the lesser variation of discretionary accruals over time indicates more predictable earnings, a lower absolute value of variation in accruals represents higher earning quality. The second one is performance-adjusted discretionary accruals following by Kothari, Leone, and Wasley (2005).

We find that the accuracy of dividend forecasts is higher than that of earnings forecasts. This result is consistent with Brown, Clarke, How, and Kadir (2000) that tested in Australian. We also find that financial analysts' dividend forecasts are more accurate when firms have higher earnings quality, suggesting that financial analysts' dividend forecasts are affected by firms' earnings quality.

The findings of this paper provide implications to investors who are interested in estimating a firm's future dividends and financial analysts' forecasts. More accurate dividend forecasts may help investors with making company valuation decisions and interpreting earnings news. Since financial analysts' dividend forecasts are likely to influence investment decisions, accurate dividend forecasts are valuable and useful to investors

Second, although literature on forecasting focus on financial analysts' earnings forecasts, interest in dividend forecasts is increasing. Recent studies have argued that the sustainable earnings is a key factor in evaluating a firm's value (Yu \& Zhao, 2015; Ruonan \& Hong, 2019). Since dividend signals cash flow implications and future performance, the result of this paper provides meaningful implications to the related literature.

\section{Prior Studies and Hypothesis}

\subsection{Financial Analysts' Forecasts}

Prior studies of financial analysts' forecasts focus on earnings forecasts and examine the characteristics of earnings forecasts, including their accuracy, optimistic bias, and forecast error (Collins \& Hopewood, 1980; Fried \& Givoly, 1982; O'Brien, 1988; Das, Levine, \& Sivaramakrishnan, 1998). Although many studies on earnings forecasts has been conducted, studies on dividend forecasts are rare. The few studies focus on the characteristics of dividend forecasts. Brown et al. (2000) examine the dividend forecasts of IPO companies in Australia and found that large-sized firms with high share ratios are more likely to have more accurate dividend forecasts. Clark, Brown, How, and Kadir (2002) find that financial analysts' dividend forecasts are more accurate and unbiased compared to their earnings forecasts. In addition, 
Brown, How, and Verhoeven (2008) use dividend forecast data from 39 countries and showed that most countries' dividend forecasts are more accurate than their earnings forecasts. Bilinski and Bradshaw (2015) also show that financial analysts' dividend forecasts are associated with market dividend expectations and, therefore, are superior to the time-series modeling method. These results suggest that financial analysts' dividend forecasts can be useful information for investors. In their study, they examine the characteristics of dividend forecasts in an international context. Using international data to investigate the accuracy of dividend forecasts, they found that their accuracy in Japan was $0.19 \%$, while those in the United States and Spain were $45 \%$ and $89 \%$, respectively. This suggests that forecast environments and the credibility of dividend forecasts vary widely across countries. However, studies on dividend forecasts are in their infancy and provide only empirical evidence about accuracy. This paper tries to expand dividend forecast research by examining the effect of earnings quality.

\subsection{Hypothesis Development}

Among accounting information, earnings play a significant role in financial analysts' forecasting activities (Basi et al., 1976; Eddy \& Seifert, 1992; Imhoff, 1992; Asgari, Salehi, \& Mohammadi, 2014; Shirzad, Mohannadi, \& Haghighi, 2015). Prior studies have found that the accuracy of earnings forecasts decreases for firms with low earnings (Eames \& Glover, 2003) and those with high accruals (Bradshaw, Richardson, \& Sloan, 2001). In Korea, Jeong, and Lim (2005) find that the accuracy of earnings forecasts decreases as firm's earnings persistence decreases. These findings suggest that earnings quality influences financial analysts' forecasts. Firms with high earnings quality provide high-quality accounting information, which positively affects financial analysts' forecasting activities. Moreover, some studies have documented the positive relationship between earnings quality and dividend policies. They report evidence that dividends provide information about earnings quality (Sant \& Cowan, 1994). This implies that high quality earnings influence a firm's dividend policy and are useful information for financial analysts' dividend forecasts.

Therefore, it is predicted that dividend forecasts are affected by earnings quality. If financial analysts use the accounting information of firms with high earnings quality, it is expected that the accuracy of firms' dividend forecasts will be higher. In sum, we predict that more predictable earnings will lead to more predictable dividend forecasts. This study set up the following hypothesis to verify this prediction.

H1: Earning quality is positively associated with the accuracy of financial analysts' dividend forecasts.

\section{Research Methodology}

\subsection{The Model}

This study has two purposes. One is comparison dividend forecasts and earnings forecasts in terms of accuracy and another is test the effect of earnings quality on financial analysts' dividend forecasts. For the former, the hypothesis is not set because the test on the difference between ADFA and AEA is the process of confirming the results of previous research in Korea. It is predicted that dividend forecasts are more accurate than earnings forecasts because forecasting earnings is relatively complicated due to many factors that affect future performance levels. A firm's future earnings are affected by both accounting performance and non-financial information, such as economic factors, industry trends, and governance. These factors make it difficult for financial analysts to predict earnings. Meanwhile, it is relatively easy for financial analysts to predict dividends because fewer variables affect dividend policies. In addition, dividend is sticky and managers tend to keep dividends unchanged (Guttman, Kadan, \& Kandel, 2010). This study compares the accuracy of dividend forecasts and earnings forecasts by calculating the accuracy in accordance with prior studies as follows:

\section{$\mathrm{ADFA}=$ absolute $(\mathrm{DFA})=$ absolute $(($ dividend forecast - actual dividend)/price)}

$\mathrm{AEA}=$ absolute $(\mathrm{EA})=$ absolute $(($ earnings forecast - actual earnings)/price)

If the values of DFA and EA are positive, it implies that the forecasts are higher than the actual values and that there is optimistic bias. Since this paper focuses on forecast accuracy rather than forecast bias, the absolute value of forecast bias is measured. Smaller values of ADFA and AEA represent more accurate forecasts in each case. To test the differences between the two values, the Wilcoxon signedrank sum test is applied. Since the distribution of ADFA does not satisfy the normal distribution assumption, it is relevant to use the Wilcoxon signed-rank sum test as a nonparametric test. Moreover, this test has the advantage of not having to adjust extreme values because it uses the rank variables rather than continuous variables. If the value of (ADFA-AEA) is negative, then ADFA is more accurate than AEA. The statistical significance of the difference is tested by Wilcoxon $\mathrm{S}(\operatorname{Pr}\rangle=|\mathrm{S}|)$.

To test the second issue, a multivariate regression model (1) is used.

$$
\begin{aligned}
\mathrm{ADFA}_{\mathrm{t}}= & \mathrm{a}_{0}+\mathrm{a}_{1} \mathrm{EQ}_{\mathrm{t}}+\mathrm{a}_{2} \mathrm{AEA}_{\mathrm{t}}+\mathrm{a}_{3} \mathrm{SIZE}_{\mathrm{t}}+\mathrm{a}_{4} \mathrm{GRW}_{\mathrm{t}}+\mathrm{a}_{5} \mathrm{LEV}_{\mathrm{t}} \\
& +\mathrm{a}_{6} \mathrm{ROA}_{\mathrm{t}}+\mathrm{a}_{7} \operatorname{lnCOV}_{\mathrm{t}}+\mathrm{a}_{8} \mathrm{LARS}_{\mathrm{t}}+\mathrm{a}_{9} \mathrm{FOR}_{\mathrm{t}}+ \\
& \mathrm{a} \sum \mathrm{IND}+\mathrm{a} \sum \mathrm{YR}+\varepsilon_{\mathrm{t}}
\end{aligned}
$$

The definition of variables are follow: 
ADFA is financial analysts' dividend forecast accuracy.

EQ is earnings quality as measured by the Francis et al. (2005) model for EQ1 (accruals quality) and the performance-adjusted accruals for EQ2 (discretionary accruals).

AEA is financial analysts' earnings forecast accuracy.

SIZE is the natural log of total asset.

GRW is the change in sales divided by total assets.

LEV is the ratio of debt to total assets.

ROA is return on assets.

$\operatorname{lnCOV}$ is the natural $\log$ of the number of financial analysts.

LARS is the percentage of large shareholders.

FOR is the percentage of foreign investors.

IND is industry fixed effect dummies and YR is year fixed effect dummies.

For earnings quality (EQ), this paper uses two variables to measure less volatile and persistent earnings. According to Bricker, Previts, Robinson, and Young (1995), financial analysts interpret earnings quality as earnings predictability, which is defined in terms of management discretion for accounting and earnings volatility for economic sense. Therefore, this paper uses two variables as proxies for earnings quality.

First is accruals quality from Francis et al. (2005). Greater variations in discretionary accruals over time indicate unpredictable future performance. Therefore, this study uses the standard deviation of the residuals from Francis et al. (2005) model to capture the predictable earnings. To measure proxies for earnings quality, the firms that has at least three years of accounting data are required. This study first measures the residuals from model (2) as discretionary accruals. Then, the standard deviations of the discretionary accruals over three years are measured. This measurement is denoted as EQ1, and it is multiplied by $(-1)$ for interpretation. It is predicted that a greater EQ1 value represents higher earnings quality.

$$
\begin{aligned}
\mathrm{ACC}_{\mathrm{t}}= & \mathrm{a}_{0}+\mathrm{a}_{1} \mathrm{CFO}_{\mathrm{t}-1}+\mathrm{a}_{2} \mathrm{CFO}_{\mathrm{t}}+\mathrm{a}_{3} \mathrm{CFO}_{\mathrm{t}+1}+\mathrm{a}_{4} \mathrm{REV}_{\mathrm{t}}+ \\
& \mathrm{a}_{5} \mathrm{PPE}_{\mathrm{t}}+\varepsilon_{\mathrm{t}}
\end{aligned}
$$

Second is a performance-adjusted discretionary accruals and denotes EQ2. Discretionary accruals reflect management discretion over adjustment of certain conservative reserve, allowances, and off-balance sheet assets. Therefore, higher discretionary accruals can be interpreted as lower earnings quality (Kim \& Lee, 2019). This study first estimates discretionary accruals from the model (3) and calculates performance-adjusted discretionary accruals according to Kothari et al. (2005) method to alleviate the effect of ROA on discretionary accruals. Since a higher discretionary accruals represents a lower earnings quality, it is also multiplied by (-1) for interpretation.

$$
\mathrm{ACC}_{\mathrm{t}}=\mathrm{a}_{0}+\mathrm{a}_{1} \Delta \mathrm{REV}_{\mathrm{t}}+\mathrm{a}_{2} \mathrm{PPE}_{\mathrm{t}}+\varepsilon_{\mathrm{t}}
$$

ADFA is a dependent variable that captures the accuracy of dividend forecasts. For easy interpretation, it is multiplied by $(-1)$. If the earnings quality measured by variations in earnings affects analysts' dividend forecast accuracy, then the coefficient of EQ is significantly positive. Model (1) includes typical control variables that are employed in the forecast literature (Eames \& Glover, 2003; Lee \& Kim, 2016). Specifically, firm size (SIZE), growth (GRW), leverage (LEV), ROA, the number of financial analysts $(\operatorname{lnCOV})$, the percentage of large shareholders (LARS), foreign investors (FOR), and industry and year fixed effect dummies (IND, YR) are included. Prior studies have reported that firm characteristics, such as size, performance, and growth, affect analysts' forecasts. Eddy and Seifert (1992) suggested that analysts' forecasts are more accurate for large firms and stable firms. The rationale explanation on this relationship is that larger firms generally have many analyst following, which contributes to aggregate information gathering. Furthermore, the number of financial analysts affects analysts' forecasts because the forecasts are synchronized (Alford \& Berger, 1999).

\subsection{Sample Selection}

This paper uses 1,387 firm-year observations from 2011 to 2015. For the final sample procedure, the observations are restricted to financial analysts' dividend forecasts. Specifically, the firms are selected if they meet the following criteria: (1) They have financial analysts' dividend forecasts, earnings forecasts, and financial information; (2) Their fiscal year ends in December; (3) They have no equity impairment; and (4) They are not in the financial industry. Dividend forecasts and financial information are obtained from the FnGuide database. Since this study focuses on firms with dividend forecasts, a sample of 1,387 firm-year observations with dividend forecasts are used for the main analysis. To minimize the impact of outliers, tests are conducted after removing outliers with absolute studentized residuals value above 2 .

Table 1 presents the number of observations depending on the dividend payers. It shows that $24.1 \%$ of dividend payers have dividend forecasts, which is low compared to other countries. Bilinski and Bradshaw (2015) examine the accuracy of dividend forecast in international setting and document that $87.9 \%$ of dividend payers have dividend forecasts, on average.

Table 1: The number of observations

\begin{tabular}{|l|c|c|}
\hline \multicolumn{3}{|c|}{ Dividend Forecast (DF) } \\
\hline & DF = 0 & DF = 1 \\
\hline Dividend payers & 4,363 & 1,387 \\
\hline Non-payers & 4,069 & 0 \\
\hline & 8,432 & 1,387 \\
\hline
\end{tabular}

Note: $\mathrm{DF}=0$ indicates firms without dividend forecasts while DF $=1$ indicates firms with dividend forecasts. Dividend payers are firms with dividend payouts while Non-payers are firms without dividend payouts. 


\section{Empirical Results}

\subsection{Descriptive Statistics}

In Table 2, the descriptive statistics of variables including the median and standard variations for all variables are reported. The DFA is a raw variable that measures the difference between the dividend forecast and dividend payments. The mean value of DFA is zero (0.000), which implies that there is no optimistic bias in the dividend forecast. However, the mean value of EA is positive (0.016). This is consistent with the findings of prior studies that the earnings forecast is optimistic (Kim, 2018). The mean value of ADFA (0.004) is positive and less than the mean value of AEA (0.027). The mean (median) values of EQ1 and EQ2 are $0.034(-0.025)$ and $0.001(0.001)$, indicating that most companies in the sample have less volatile earnings and less earnings management. The mean value of the number of financial analysts (COV) is 6.015, suggesting that six financial analysts are predicting a firm's dividends, on average.

Table 2: Descriptive statistics

\begin{tabular}{|c|c|c|c|c|c|}
\hline Variables & Min & Mean & Median & Max & STD. \\
\hline$D F A$ & -0.056 & 0.000 & 0.000 & 0.081 & 0.008 \\
\hline$E A$ & -0.732 & 0.016 & 0.006 & 0.706 & 0.065 \\
\hline EQ1 & -0.314 & -0.034 & -0.025 & 0.000 & 0.032 \\
\hline EQ2 & -0.165 & 0.001 & 0.001 & 0.303 & 0.020 \\
\hline$S I Z E$ & 17.146 & 20.614 & 20.364 & 26.213 & 1.776 \\
\hline$R O A$ & -0.136 & 0.061 & 0.051 & 1.527 & 0.070 \\
\hline $\ln (\mathrm{COV})$ & 0.000 & 1.141 & 0.693 & 3.434 & 1.139 \\
\hline COV & 1.000 & 6.015 & 2.000 & 31.000 & 6.998 \\
\hline LARS & 5.990 & 42.850 & 41.230 & 100.000 & 16.216 \\
\hline FOR & 0.000 & 15.003 & 10.985 & 89.733 & 14.512 \\
\hline
\end{tabular}

Note: Refer to Equation 1 for the definition of variables.

Table 3 shows the number of observations, dividend forecast accuracy, and earnings forecast accuracy over time. The number of observations increase over time, suggesting that financial analysts predict dividends as well as earnings actively. Specifically, ADFA is smaller than AEA over time. The ADFA has a stable trend over time, while the AEA is volatile, suggesting that dividend forecasts are more predictable than earnings forecasts.

Table 3: The number of observations, ADFA, and AEA over time

\begin{tabular}{|c|c|c|c|}
\hline Year & N & ADFA & AEA \\
\hline 2011 & 156 & 0.004 & 0.028 \\
\hline 2012 & 181 & 0.004 & 0.023 \\
\hline 2013 & 272 & 0.003 & 0.024 \\
\hline 2014 & 353 & 0.003 & 0.029 \\
\hline 2015 & 425 & 0.003 & 0.028 \\
\hline Total & 1,387 & 0.004 & 0.027 \\
\hline
\end{tabular}

Note: ADFA and AEA are the accuracy of dividend forecasts and earnings forecasts, respectively.

Table 4 presents the univariate test results. Results are reported from the t-test for mean value and the Wilcoxon test for median value, respectively.

The difference between ADFA and AEA is significantly negative, which means that the ADFA value is smaller than the AEA value. The result from the mean (median) of ADFA and AEA supports this study's prediction and is consistent with prior findings. It is easier for financial analysts to forecast dividends because a firm tend to maintain dividend policy.

Table 4: Test on differences between ADFA (MADFA) and AEA (MAEA)

\begin{tabular}{|l|c|c|c|}
\hline \multicolumn{2}{|c|}{} & $\begin{array}{c}\text { DFA } \\
\text { (ADFA- } \\
\text { AEA })\end{array}$ & $\begin{array}{c}\text { MDFA } \\
\text { (MADFA- } \\
\text { MAEA) }\end{array}$ \\
\hline \multirow{2}{*}{$\begin{array}{l}\text { Test (M)DFA } \\
=0\end{array}$} & & -0.023 & -0.007 \\
\cline { 2 - 4 } & $(\operatorname{Pr}>=|t|)$ & $-14.81^{* *+}$ & \\
\cline { 2 - 4 } & $(\operatorname{Pr}>=|S|)$ & & $-379842^{* *+}$ \\
\hline
\end{tabular}

Note: This table presents the univariate test results. The mean (medians) of ADFA (MDFA) and AEA (MAEA) are compared, and the statistical test results of the differences of the means (medians) are reported. ${ }^{* * *}$, ${ }^{* *}$, and ${ }^{*}$ represent statistical significances of $1 \%, 5 \%$, and $10 \%$, respectively.

We begin with a group test to find the association between earnings quality and dividend forecast accuracy. Table 5 reports the AFDA and AEA for the lowest EQ group (G1) and the highest EQ group (G5) as well as the difference between the two groups. The results show that the dividend forecast accuracy (AFDA) in G5 is greater than that of G1. In addition, the difference between the two groups is positive and significant in t-value for the mean and Wilcoxon for the median, respectively. The AEA findings show a similar result. Therefore, the results in Table 5 confirm our prediction that earnings quality of a firm positively affects the accuracy of dividend forecasts. However, this result shows a simple relationship between two variables and does not control for any variables that affect dividend policy. Thus, a multivariate test is performed 
for robustness.

Table 5: The relationship between EQ and dividend forecast accuracy

\begin{tabular}{|l|c|c|c|c|c|}
\hline & $\begin{array}{c}\text { G1 } \\
\text { (High } \\
\text { EQ1) }\end{array}$ & $\begin{array}{c}\text { G5 } \\
\text { (Low } \\
\text { EQ1) }\end{array}$ & $\begin{array}{c}\text { Diff } \\
\text { (G1-G5) }\end{array}$ & $\begin{array}{c}\text { t- } \\
\text { value }\end{array}$ & Wilcoxon \\
\hline$A D F A$ & 0.0030 & 0.0050 & 0.002 & $3.18^{* * *}$ & $3.126^{* * *}$ \\
\hline$A E A$ & 0.0221 & 0.0425 & 0.020 & $3.01^{* * *}$ & $1.715^{* *}$ \\
\hline
\end{tabular}

Note: ${ }^{* *},{ }^{* *}$, and ${ }^{*}$ represent statistical significances of $1 \%, 5 \%$, and $10 \%$, respectively.

\subsection{Regression Results}

Regression analysis is initiated with EQ in ordinary least squares regression (OLS) to find out the effect of earnings quality on the accuracy of dividend forecasts. We additionally perform Fama-Macbeth analysis to address a cluster of observations. The coefficients of EQ1 and EQ2 are 1.044 (t-value: 6.49) and 1.736(t-value: 9.15), respectively. Table 6 presents the regression results. Specifically, the coefficient of EQ1 in model (1) is positive and statistically significant (2.104, t-stat: 3.67$)$. This means that the accuracy of dividend forecasts increases as earnings quality increases. In addition, equation (1) is tested with EQ2 and the result from EQ2 is reported in model (3) and (4) and is identical to the model (1) result. This indicates that earning quality affects the accuracy of dividend forecasts. Following prior studies, this study controls for variables that affect dividend forecasts, such as size, growth, leverage, ROA, the number of analysts, the percentage of large shareholders and foreign shareholders, year, and industry. The accuracy of earning forecasts (AEA) is also controlled because it is predicted that financial analysts provide similar forecast characteristics. As predicted, the coefficient of AEA is significantly positive, which implies a positive relationship between dividend forecasts and earnings forecasts in terms of accuracy.

Table 6: Regression results

\begin{tabular}{|c|c|c|c|c|c|}
\hline Variables & Pred. & $\begin{array}{c}\text { (1) } \\
\text { EQ1 } \\
\text { Coefficient } \\
\text { (t-stat.) }\end{array}$ & $\begin{array}{c}\text { (2) } \\
\text { EQ1 } \\
\begin{array}{c}\text { Coefficient } \\
\text { (t-stat.) }\end{array}\end{array}$ & $\begin{array}{c}\text { (3) } \\
\text { EQ2 } \\
\text { Coefficient } \\
\text { (t-stat.) }\end{array}$ & $\begin{array}{c}\text { (4) } \\
\text { EQ2 } \\
\text { Coefficient } \\
\text { (t-stat.) }\end{array}$ \\
\hline$E Q$ & + & (3.67) & $(1.82)$ & (1.84) & $(2.46)$ \\
\hline \multirow{2}{*}{$A E A$} & \multirow{2}{*}{+} & & $0.041^{1 * t+}$ & & $0.041^{1 *+*}$ \\
\hline & & & $(14.04)$ & & $(14.39)$ \\
\hline$S I Z E$ & + & 0.022 & $0.042^{2 *+*}$ & 0.028 & $0.048^{* *+*}$ \\
\hline \multirow{2}{*}{ GRW } & \multirow{2}{*}{+} & 0.046 & 0.012 & 0.051 & 0.032 \\
\hline & & $(1.41)$ & $(0.38)$ & $(1.50)$ & $(0.95)$ \\
\hline \multirow{2}{*}{ LEV } & \multirow{2}{*}{-} & $-0.200^{*}$ & 0.071 & $-0.235^{* *}$ & 0.075 \\
\hline & & $(-1.72)$ & $(0.64)$ & $(-2.02)$ & $(0.69)$ \\
\hline \multirow{2}{*}{$R O A$} & \multirow{2}{*}{+} & 0.006 & $0.930^{*+*+1}$ & -0.230 & $0.861^{1 * *+}$ \\
\hline & & $(0.02)$ & $(3.41)$ & $(-0.83)$ & (3.24) \\
\hline FOR & $+/-$ & $(-2.33)$ & $(-3.17)$ & $(-2.04)$ & $(-2.95)$ \\
\hline \multirow{2}{*}{ Intercept } & \multirow{2}{*}{$+/-$} & $-0.815^{*}$ & $-1.402^{* * *}$ & $-0.990^{*+}$ & $-1.532^{* * * t}$ \\
\hline & & $(-1.76)$ & $(-3.29)$ & $(-2.13)$ & $(-3.61)$ \\
\hline IND dummy & & Included & Included & Included & Included \\
\hline YEAR dummy & & Included & Included & Included & Included \\
\hline Adj. $R^{2}$ & & 0.061 & 0.182 & 0.054 & 0.184 \\
\hline
\end{tabular}

Note: ${ }^{* * *},{ }^{* *}$, and ${ }^{*}$ represent statistical significances of $1 \%, 5 \%$, and $10 \%$, respectively

\section{Conclusion}

Although a significant amount of empirical evidence exists on the characteristics of earnings forecasts and the effect of earnings quality, few studies can be found in the literature on financial analysts' dividend forecasts and the effect of earnings quality thereon. This paper attempts to explore the variables that affect dividend forecast characteristics and to test whether a firm's earnings quality affects the accuracy of dividend forecasts. It is predicted that more predictable earnings positively affect the accuracy of dividend forecasts. A univariate test is performed with the lowest (highest) EQ groups and the accuracy of dividend forecasts and multivariate regression with control variables. Consistent with the prediction, we find that firms with high earnings quality show more accurate dividend forecasts. Moreover, the magnitude of coefficient of EQ is greater than that of other variables in the model. It indicates that the impact of earnings quality on the accuracy of dividend forecasts is meaningful. This result suggests that earnings 
characteristics are important factors in determining the accuracy of dividend forecasts, confirming that higher earnings quality positively influences financial analysts' dividend forecasts.

The findings of this paper provide several contributions to related studies. First, the empirical results on financial analysts' dividend forecasts provide useful information to participants in the market. Recently, as interest in dividend payouts has increased, the demand for dividend forecast information has grown. Dividends have cash flow implications for investors and are signaling devices (Brown et al., 2002; Hahn \& Kim, 2016). More accurate dividend forecast is very useful for investors to make proper decisions because they use forecasts as important input in their decision making.

Second, the findings of this paper confirm that earnings quality influences financial analysts' dividend forecasts. This result helps to enhance the interpretation of financial analysts' forecasts. Prior studies provide empirical evidence on characteristics of earnings forecasts, but few studies have been conducted on dividend forecasts. This paper contributes to related literature by providing evidence on the accuracy of dividend forecasts and extending existing studies to dividend forecasts. Third, the dividend models in valuation literature are used under the assumption that past dividend patterns (or the same dividend policies) will continue. However, this is an assumption rather than a prediction. If the accurate dividend forecast is used as future dividends in the model, the intrinsic value of a firm is more accurate and credible. This paper provide empirical evidence on the variables that affect dividend forecasts accuracy. Finally, this paper contributes to expanding financial analyst studies. Although research on dividend forecasts has recently been conducted, it is in its initial stages and focuses on the accuracy of dividend forecasts (Bilinski \& Bradshaw, 2015; Brown et al., 2008). Further research can expand this work to test the other characteristics of dividend forecasts, the effect of financial analysts' characteristics, market reaction, the effect of dividend forecasts on investors' decisions, and so on.

\section{References}

Alford, A. W., \& Berger, P. G. (1999). A simultaneous equations analysis of forecasts accuracy, analysts following and trading volume. Journal of Accounting, Auditing \& Finance, 14(3), 219-246.

Asgari, L., Salehi, M., \& Mohammadi. A. (2014). Incremental information content of cash flow and earnings in the Iranian capital Market. The International Journal of Industrial Distribution \& Business, 5(1), 5-9.

Basi, B., Carey, K., \& Twark, R. (1976). A comparison of the accuracy of corporate and security analysts' forecasts of earnings. The Accounting Review, 51(2), 244-254.
Bilinski. P., \& Bradshaw. M. (2015). Analyst dividend forecasts and their usefulness to investors: International evidence (Working paper). doi:10.2139/ssrn2677094.

Bradshaw, M., Richardson, S. A., \& Sloan, R. (2001). Do analysts and auditors use information in accruals? Journal of Accounting Research, 39(1), 45-74.

Bricker, R., Previts, G., Robinson, T., \& Young, S. (1995). Financial analyst assessment of company earnings quality. Journal of Accounting, Auditing \& Finance, 10(3), 541-554.

Brown, P., Clarke. A., How. J. Y., \& Kadir, L. (2000). The accuracy of management dividend forecasts. PacificBasin Finance Journal, 8(3-4), 309-331.

Brown, P., How. J. Y., \& Verhoeven, P. (2008). The accuracy of analysts' dividend forecasts around the world. Pacific-Basin Finance Journal, 16(4), 411-435.

Clark, A., Brown, P., How, J. Y., \& Kadir, L. (2002). Analysts' dividend forecasts. Pacific-Basin Finance Journal, 10(4), 371-392.

Collins, W., \& Hopewood, W. (1980). A multiple analysis of annual earnings forecasts generated from quarterly forecasts of financial analysts and univariate time series models. Journal of Accounting Research, 18(2), 390-406.

Daniel, K., \& Titman, S. (2006). Market reactions to tangible and intangible information. Journal of Finance, 61(4), 1605-1643.

Das, S., Levine, C., \& Sivaramakrishnan, K. (1998). Earnings predictability and bias in analysts' earnings forecasts. The Accounting Review, 73(2), 277-294.

Eames, M., \& Glover, S. (2003). Earnings predictability and the directing of analysts' earnings forecast errors. The Accounting Review, 78(3), 707-724.

Eddy, A., \& Seifert, B. (1992). Firm size and dividend announcement. The Journal of Financial Research, 11(4), 295-302.

Foster, T., \& Vickrey, D. (1978). The incremental information content of the 10-K. The Accounting Review, 53(4), 921-934.

Francis, J., LaFond, R., Olsson. P., \& Schipper, K. (2004). Costs of equity and earnings attributes. The Accounting Review, 79(4), 967-1010.

Francis, J., LaFond, R., Olsson. P., \& Schipper, K. (2005). The market pricing of accruals quality. Journal of Accounting and Economics, 39(2), 295-327.

Fried, D., \& Givoly, D. (1982). Financial analysts' forecasts of earnings: A better surrogate for market expectations. Journal of Accounting and Economics, 4(2), 85-107.

Guttman, I., Kadan, O., \& Kandel, E. (2010). Dividend stickiness and strategic pooling. The Review of Financial Studies, 23(12), 4455-4495.

Hahn, Y. N., \& Kim, D. H. (2016). Corporate social responsibility: A comparison analysis. The Journal of Business, Economics, and Environmental Studies, 6(4), 13-17.

Hwang, L., Jan, C., \& Basu, S. (1996). Loss firms and analysts' earnings forecast errors. Journal of Financial Statement Analysis, 1(2), 18-31. 
Imhoff, E. (1992). The relation between perceived accounting quality and economic characteristics of the firm. Journal of Accounting and Public Policy, 11(2), 97-118.

Jeong, D. B. (2017). Prediction of sales on some large-scale retailing types in South Korea. The Journal of Business, Economics, and Environmental Studies, 7(4), 35-41.

Jeong, S. W., \& Lim, T. K. (2005). The effect of earnings persistence on analysts' forecast error and accuracy. Korean Accounting Review, 30(2), 209-235.

Kim, S. S., \& Lee, J. H. (2019). Corporate social responsibility and financial reporting quality: Evidence from Korean retail industry. Journal of Distribution Science, 17(6), 33-42.

Kim, Y. D. (2018). The effect of prior price trends on optimistic forecasting. The International Journal of Industrial Distribution \& Business, 9(10), 83-89.

Kothari, S., Leone, A., \& Wasley, C. (2005). Performance matched discretionary accrual measures. Journal of Accounting and Economics, 39(1), 163-197.

Lee, J. H., \& Kim, S. S. (2016). Corporate governance and the marginal cash value for Korean retail firms. Journal of Distribution Science, 14(5), 27-37.
Lee, J. H., \& Kim, S. S. (2017). Testing the liquidity hypothesis in the Korean retail firms. Journal of Distribution Science, 15(5), 29-38.

O'Brien, P. (1988). Analysts' forecasts as earnings expectations. Journal of Accounting and Economics, 10(1), 53-83.

Ruonan, Z., \& Hong, Y. (2019). Corporate social responsibility disclosure, financing constraints and investment-cash flow sensitivity. The Journal of Business, Economics, and Environmental Studies, 9(1), 21-28.

Sant, R., \& Cowan, A. (1994). Do dividends signal earnings? The case of omitted dividends. Journal of Banking and Finance, 18(6), 1113-1133.

Shirzad, A., Mohannadi, S., \& Haghighi, R. (2015). Effect of financial performance on earnings management in the Drug distribution industry. The International Journal of Industrial Distribution \& Business, 6(4), 23-26.

Yu, M., \& Zhao, R. (2015). Sustainability and firm valuation: an international investigation. International Journal of Accounting and Information Management, 23(3), 280307. 